\title{
O dinheiro no casamento: questões de gênero
}

O casal, o amor e o dinheiro: a construção conjugal das dimensões econômicas da relação amorosa.

HENCHOZ, Caroline.

Paris: L'Harmattan, 2008. 261 p.

\section{O dinheiro do amor}

Em O casal, o amor e o dinheiro, Caroline Henchoz analisa o dinheiro, sua circulação no casal e sua utilização como base e expressão do sentimento amoroso. Essa é uma proposta particularmente interessante em um contexto em que a vida conjugal e a família não são sempre institucionalizadas pelo casamento ou pelo Pacto Civil de Solidariedade - Pacs e em que muitas uniões são rompidas. Outros autores, antropólogos, historiadores e sociólogos, têm mesmo demonstrado que contribuições, doações e transações "aparecem como outras formas de legitimar, valorizar ou fabricar as relações e os status em movimento, às vezes não reconhecidos pelo direito ou pelos costumes". O dinheiro fala dos vínculos amorosos, ao mesmo tempo que os usos que dele fazem 
os que participam de sua construção. Mas não se trata de ceder à tentação do amor romântico ou, para retomar as expressões utilizadas pela autora, "à ideologia amorosa da reciprocidade e do equilíbrio das trocas" (p. 49), particularmente importante nas fases iniciais da história conjugal.

Baseando-se nos depoimentos coletados, e também nos trabalhos de Viviana Zelizer e Erving Goffman, a autora demonstra que essa ideologia igualitária é muito cedo contrariada pelos "códigos de galanteio masculinos", que, como Goffman muito bem mostrou, se apoiam na assimetria entre os sexos. Se o dom é valorizado nas esferas conjugal e familiar, ele exige o contradom sobre o qual os trabalhos mais antigos de Viviana Zelizer e Jacques $\mathrm{T}$. Godbout, reatualizando os de Marcel Mauss, mostram toda a sua importância nas relações interpessoais e, em especial, nas relações de parentesco. Todavia, o dinheiro, mesmo que, posto em circulação sob os auspícios do altruísmo, do amor e do desinteresse, revele também as discussões e as negociações intraconjugais que muitos preferem deixar silenciadas, pode contribuir para fortalecer as relações desiguais e alimentar as relações de poder e persiste mesmo, como pode mostrar Agnés Martial, para manter os laços supostamente rompidos.

Com o tempo de coabitação, poucos casais conseguem manter uma forma de gestão individual dos recursos e das despesas. Quando se confirma a vontade de cada um se engajar em um projeto de futuro conjugal comum, a partilha das fontes de renda realizada por muitos dos casais entrevistados por Caroline Henchoz mantém um funcionamento duplo. Cada um pode continuar a utilizar seu próprio dinheiro, principalmente para dar presentes ao parceiro. Ao mesmo tempo, as despesas ligadas à vida em comum são divididas, muitas vezes em partes iguais quando os dois têm renda, mas também a partir da base de cálculos através da qual cada um contribui proporcionalmente de acordo com seus rendimentos. Um sistema reivindicado como igualitário, mas Caroline Henchoz mostra, mantém formas de desigualdade, notadamente quando se considera o montante que sobra dos rendimentos não partilhados em casais cujos salários são muito díspares. A socióloga também mostra que, ao longo da biografia conjugal, um elemento bem conhecido da literatura sociológica que marca, mais do que qualquer outro, as mudanças importantes na maneira de gerir as finanças do casal é a chegada de uma criança. Não só as necessidades ligadas à educação da criança tornam-se prioridades, mas a sua chegada leva muitos casais, que até então eram inquilinos, a adquirirem um imóvel.

A autora baseia-se em teorias sociológicas segundo as quais a comunicação conjugal leva os parceiros, já portadores de "representações ligadas a seu gênero, (suas) experiências e concepções da realidade" (p. 13), a compartilharem uma mesma visão de mundo. Façamos duas observações a esse propósito. Por um lado, isso não deve apagar as possíveis divergências, por vezes duradouras, que podem permanecer no seio do casal ou em outros campos da vida conjugal sobre o domínio da gestão do dinheiro. Por outro lado, as contribuições dos americanos John Gagnon e W. Simon à sociologia da sexualidade podem ser igualmente úteis para dar conta das dinâmicas no seio do casal. ' A autora poderia ter ampliado a análise dos sociólogos americanos e se referir a eles quando evoca os níveis institucionais (contextual ou social), interacional ("conjugal") e individual para analisar o "sexo social do dinheiro" (p. 138).

\section{O gênero do dinheiro}

Colocar em comum parte dos recursos, o que deixaria, portanto, uma parte dos recursos para uso pessoal, não significa que se possa usar o dinheiro pessoal com toda liberdade. O outro em particular quando é aquele que ganha a maior parte da receita (e esse é, sem surpresa, na maioria das vezes o homem), preserva em alguns casais o direito de não compartilhar suas despesas pessoais. Os jogos de poder não desaparecem sob a ideologia romântica nem sob a lógica da partilha comum parcial dos recursos. Assim, Caroline Henchoz confirma com sua pesquisa tendências já conhecidas e que permanecem fortes. Nos casais suíços encontrados, na maioria das vezes as mulheres são as responsáveis pelas despesas domésticas cotidianas. Os homens se encarregam mais frequentemente dos ganhos e da gestão "conjunta das contas do lar" (p. 130-131). A gestão do dinheiro permanece muitas vezes submissa a uma repartição sexuada dos papéis (o dinheiro masculino sendo geralmente mais valorizado que o dinheiro das mulheres) e das responsabilidades. Dessa forma, ela contribui diretamente, perpassada por outros atos e gestos, para a "produção do gênero" (p. 152).

Todos os casais não colocam em evidência processos de negociação e negociam mesmo quando não pensam que estão fazendo; a 
instalação do casal no tempo e a chegada das crianças são os fatores que parecem favorecer esses processos. Além do fato de mostrar que cada parceiro não é igual ao outro, Caroline Henchoz mostra, sobretudo, que um e outro não dispõem dos mesmos recursos para negociar. 0 nível de renda pessoal, o desequilíbrio das "relações de poder", o caráter espontâneo do dom, podem ser obstáculos para a implementação de uma negociação intraconjugal equilibrada. Em suma, a identidade de gênero de cada um dos membros do casal, homem ou mulher, supõe que não podem negociar da mesma maneira nem sobre as mesmas questões, permanecendo como um fator determinante nos usos conjugais do dinheiro.

O trabalho de Caroline Henchoz é sem dúvida de grande importância sobre vários pontos de vista. Seu primeiro mérito é contribuir, com outros autores, para a renovação de um campo da sociologia da família e da antropologia do parentesco, esquecido nos últimos anos pela literatura francófona. Como em outras pesquisas a respeito do trabalho doméstico e da sexualidade, esta obra mostra que, apesar do impacto das normas sociais preconizando a igualdade entre os sexos, os fatos observados no casal e na família resistem aos discursos igualitários, principalmente quando o casal se mantém durável no tempo e com a chegada das crianças. Este livro, muito erudito, fornece ao leitor inúmeras referências bibliográficas da literatura sociológica e antropológica europeia e norte-americana muito úteis para os interessados nessas questões. Para além do caso da sociedade suíça, este livro contribui para a renovação do conhecimento dos funcionamentos conjugais que se dão em todas as sociedades contemporâneas. Ele mostra também como a circulação do dinheiro e dos bens imateriais e materiais, no âmbito da esfera conjugal e familiar, traduz e constrói os sentimentos. Assim, este trabalho ilustra, se é que isso é necessário, como o amor e a igualdade conjugal nem sempre andam de mãos dadas.

\section{Nota}

' CAGNON, 2006

\section{Referência bibliográfica}

CAGNON, Jhon. Uma interpretação do desejo: ensaios sobre o estudo da sexualidade. Rio de Janeiro: Garamond, 2006.

Jérôme Courduriès

Centre Norbert Elias CNRS Tradução: Cláudia Nichnig Revisão: Miriam Pillar Grossi 